\title{
Regional Cooperation in East Java Province, Indonesia: Selfishness and Necessity
}

\author{
Ardhana Januar Mahardhani ${ }^{1,2 *}$, Sri Suwitri ${ }^{3}$, Soesilo Zauhar $^{4}$, Hartuti Purnaweni ${ }^{3}$ \\ ${ }^{1}$ Doctoral Programme of Public Administration, Diponegoro University, Semarang, Indonesia \\ ${ }^{2}$ Universitas Muhammadiyah Ponorogo, Ponorogo, Indonesia \\ ${ }^{3}$ Faculty of Social and Political Science, Diponegoro University, Semarang, Indonesia \\ ${ }^{4}$ Faculty of Administrative Science, Brawijaya University, Malang, Indonesia \\ ${ }^{*}$ Corresponding author. Email: ardhana@umpo.ac.id
}

\begin{abstract}
Regional cooperation among local government is a must for the efficient management of public administration. The state has been implementing regulations on such cooperation. However, there are regions which reluctant to cooperate, especially with the adjacent areas. This method used is the study of literature, this paper will conduct an in-depth exploration of collaborative activities in Selingkar Wilis in East Java Province. Selingkar Wilis consists of six regencies (Tulungagung, Trenggalek, Ponorogo, Madiun, Nganjuk, and Kediri). These areas are provincial strategic areas which will be developed into a new tourism destination. Moreover, according to the preliminary study there are some problems hampering such cooperation, due mainly to regional selfishness. Therefore, this paper shows various regional cooperation models that aims to illustrate the cooperation among regions. These efforts are a must for the better development management among Selingkar Wilis areas. From the results of the study in the model offered for inter-regional cooperation activities, what is appropriate is the joint secretariat, which consists of three components, namely the local government, the private sector, and the daily executive board.
\end{abstract}

Keywords: regional cooperation, cooperation models, joint secretariat

\section{INTRODUCTION}

There has been much discussion about inter-governmental cooperation, however the output of cooperation is more highlighted than how the cooperation process was built, the forms of negotiations that have been built, the values and interests that are highlighted, as well as the organization of each region in the context of developing their respective regions. Yudhoyono, [1] explained that inter-regional cooperation was built because there was an awareness among the regions involved in cooperation to conduct: sharing of experience, where space for regions to share experiences in managing regional government affairs, the establishment of cooperation also allowed regions to share profits (sharing of benefits) from the arena of cooperation built, cooperation allows regions to share the burden (sharing of burdens). Cooperation between regions can only be formed and run if it is based on the awareness that these regions need each other to achieve one goal. Therefore, the initiation of cooperation between regions can only be carried out effectively if similar issues, common needs or common problems have been found. This similarity is used as the basis for bringing together regions to be partners, with the principles of cooperation between these regions.

One form of interconnection and interdependence that occurs is the big dream of the Government of the Province of East Java will be the formation of an integrated area with regional development based on regional locality. East Java Province is a strategic province in Indonesia because it is the gateway to the economy in eastern Indonesia. The important role of the Province of East Java in the economy of other regions in Indonesia, in terms of political geography and economic geography, positions East Java Province as the center of gravity in Indonesia.

The implementation of the understanding to cooperate between regencies in East Java Province is still not a lot of success, this is because the sectoral ego is still high, so many memorandum of understanding in the Province of East Java whose implementation is limited to a memorandum of understanding, not to an inter-regional cooperation let alone form an inter-regional cooperation institutions that are official and settled, this can be seen in research conducted by Badan Perencanaan Pembangunan Daerah of East Java Province [2]-[6], from some of these studies it can be concluded if the cooperation that is established is still not optimal and less effective. Nevertheless, East Java Province actually always supports the implementation of existing cooperation between regencies or cities in its region, this can be seen from the formation of the Regional Cooperation Coordination Team (TKKSD) based on East Java Governor Decree number 188/255/KPTS/013/2016 led by the Regional Secretariat facilitated by the Bureau of Public Relations, Protocol and Cooperation of East Java Province. Currently East Java Province is developing an area in the form of opening a new strategic area, which is a district located around Mount Wilis. There are six regencies located in the vicinity, namely Tulungagung Regency, Trenggalek Regency, Ponorogo Regency, Madiun Regency, Nganjuk Regency, and Kediri Regency, hereinafter referred to as Selingkar Wilis. In 2014, initiated by the provincial government of East Java, through a memorandum of 
understanding that was made, the six districts around Mount Wilis formed an agreement on projections for a partnership to be developed between the six districts.

From the description above, in this paper we will convey how the ideal pattern if the six districts in East Java Province will be held in cooperation.

\section{LITERATURE REVIEW}

Below is a literature review that is used in the context of discussions about writing about egoism and the need for cooperation between regions.

\subsection{Inter-regional cooperation theory}

Ramses and Bowo, explained that cooperation is the existence of two or more parties that will be dynamically connected to achieve a goal that is expected to be shared [7]. There are three main elements that can be seen in a framework of cooperation, namely two or more parties, interaction, and shared goals. Keban, explains a number of strategic issues that are the main points of inter-regional cooperation implementation, namely (1) improving the role and ability of the province in organizing inter-regional cooperation functions or "local government cooperation", (2) determining areas that should be cooperated, and (3) choosing cooperation models that are in accordance with the nature of these fields [8].

Meanwhile Flo Frank and Anne Smith, stated that cooperation can be defined as a relationship between two or more parties that have a common goal, which promises to do something together [9]. Lembaga Administrasi Negara that cooperation is about people who cooperate together in a beneficial relationship, always doing things together which may not be achieved alone [10]. Moreover, intergovernmental cooperation is defined as an arrangement between two or more governments to achieve common goals, provide a service or solve one another's problems together.

From the definition of cooperation above, it can be concluded that inter-regional cooperation is an action, activity or business carried out jointly by two or more parties, which is carried out in order to achieve a common goal to regulate and manage the interests of the community. Discussions about cooperation between regions have been widely carried out, however, in many publications it only emphasizes the outcome of the collaboration, about how the process is built up, what values and interests are negotiated, strategies and models, relationships and organizing involving aspects of government; public; and the private sector is still lacking.

\subsection{Speaking in brief explanation}

The form of cooperation is a very important thing to do at the first time when deciding to collaborate between regions, considering the form of cooperation that will be carried out in the future will greatly affect the efficiency and effectiveness of public services. Mandell, mentions the theory of pure inter-regional cooperation forms [11], starting from the theoretical base form and progressing to the coordination of temporary to permanent task forces and /or regular coordination to coalition network structures, such as the following scheme:

\begin{tabular}{|ll|}
\hline & Interlocal Collaborative \\
\hline & Activity \\
Informal & Formal \\
Low resource requirement & High resource requirement \\
Loose linkages & Thigt linkages \\
Short term & Long term \\
Simple & Complex \\
\hline
\end{tabular}

Figure 1 Inter-regional cooperation activities: mandell series

The form of cooperation between the Mandell regions is still unclear if it will be used as an archetype towards coordination in an inter-regional coalition network, the improvement of the Mandell series is seen in the Michigan Suburbs Alliance series where the picture and challenges of cooperation are increasingly clear, namely from easy to severe, from agreements formal reciprocal assistance to more informal consolidations [12].

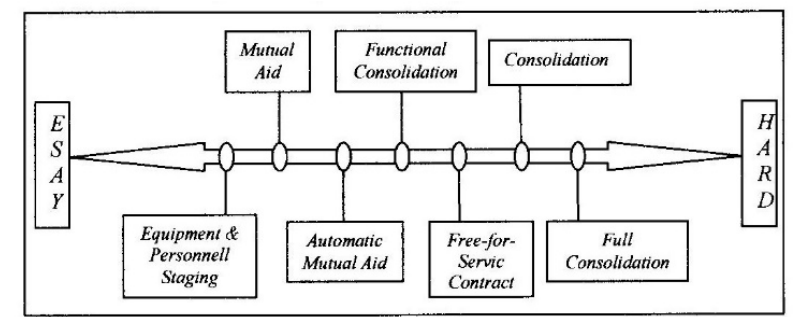

Figure 2 Cooperation series scheme Michigan suburbs alliance

Henry in Warsono, explained the form of cooperation between regional governments [13], which included: (1) intergovernmental service contract, conducted when an area pays another area to carry out certain types of services such as prison, garbage disposal, animal or livestock control, tax assessment (2) joint service agreements, carried out to carry out the functions of planning, budgeting and providing certain services to the local communities involved, for example in the regulation of regional libraries, communication between police and fire department, fire control, garbage disposal, and (3) intergovernmental service transfer, is a permanent transfer of a responsibility from one area to another such as public works, infrastructure and facilities, health and welfare, government and public finance.

Cooperation between local governments can be done in several forms, namely the form of agreements and forms of regulation. Gary, mentions forms of cooperation between local governments, including: (1) Handshake Agreement, characterized by the absence of formal cooperation agreement documents [14]. (2) Fee for service contracts (service agreements), are one area "selling" a form of public service in another area. (3) Joint Agreements, require participation or involvement of the regions involved in the provision or management of public services. (4) Jointlyformed authorities. In Indonesia, this system is more 
popular as the Joint Secretariat. The relevant local government agrees to delegate control, management and responsibility to a body that is formed jointly and usually consists of representatives of the relevant local government. (5) Regional Bodies, this system intends to form a joint body that handles general issues that are greater than local issues in one region or regional issues.

\subsection{Principle of inter-regional cooperation}

Peck, states that cooperation between regions cannot be separated in the framework of developing intergovernmental networks, in each region it cannot carry out its own activities, in its development the region always needs the surrounding area which is still in one cluster [15]. To be able to push in this direction, development and management of inter-regional cooperation must be put in the principles of equal, synergistic and mutually beneficial partnerships, based on needs, encouraging participation, flexible, legitimate, effective-efficient, accountable, and sustainable. According Pratikno, the management and development of regional cooperation, should be placed on the following principles [16]: equal partnership, synergistic and mutually beneficial, based on needs, engagement and ownership, flexible, legitimate, effective, accountable and transparent, and sustainable.

In principle, based on the above mentioned, the implementation of inter-regional cooperation must not be political, therefore inter-regional cooperation is a means of conducting regional government affairs, and the intended cooperation is in the framework of efficiency and effectiveness of public services, and is able to provide benefits for each the parties involved in interregional cooperation

\section{METHOD}

The method used is the study of literature, this paper will conduct an in-depth exploration of collaborative activities in Selingkar Wilis, East Java Province, which is known through a literature study that is available with juxtaposed with relevant theories so that it becomes the basis for further research.

The study locations in this paper are six districts in Selingkar Wilis, East Java Province, namely: Tulungagung Regency, Trenggalek Regency, Ponorogo Regency, Madiun Regency, Nganjuk Regency, and Kediri Regency. One of the reasons for choosing this research location is the existence of Selingkar Wilis which is one of the active trade centers with superior commodities in the form of agricultural, plantation, livestock, and forestry products, and the Selingkar Wilis area is one of the areas developed by East Java Province in the form of Regions Strategic Provincial Tourism (KSPP).

\section{RESULTS AND DISCUSSION}

\subsection{Egoism in Inter-regional cooperation}

Regional selfishness is still a serious and very massive problem, many regions are actually not developed because the regions are very selfish, are not willing to relate to other regions and consider their own regions to be better. The development of decentralization provided by the government has resulted in an increasingly ego-centric region and sometimes does not consider other regions, moreover those regions are lower than their regions.

Many things make regional selfishness arise, including the existence of community income gaps, different resources, unequal infrastructure development, to the difference in the speed of service provided by the government to the community, if things like that are not immediately muted then regional egoism will the higher and the regions feel capable so that it will be difficult to be invited to cooperation, this will be contrary to what was conveyed by Flo Frank and Anne Smith that cooperation must have a common goal and will carry out activities that are planned together as well.

The selfish situation is also found in inter-regional cooperation in the Selingkar Wilis Region of East Java Province which at present is still floating, there is a cooperation agreement and it is signed but not implemented properly, so that for this the region runs independently according to the regional strategic plan and vision regional leadership.

Uniting into one voice in the synergy of development in the framework of inter-regional cooperation is not easy, of the six districts in the Selingkar Wilis Region have a history of inter-regional cooperation that is not good (Laporan Pertanggungjawaban Gubernur East Java Province [17]; Mahardhani [18]; Ma'ruf [19]; Mustafa [20]).

\subsection{Regional needs to inter-regional cooperation}

Regional needs will emerge not in all sectors, in each region the emergence must be different, but even so it will usually appear in strategic areas (propulsive sector) so that it will have an impact on the progress of development in the region. Furthermore, from this strategic area, new regions with high economic value will emerge, this is in line with the East Java Provincial Government's plan to open the Selingkar Wilis Region.

In the current industrial era highlighting solitude in developing regions is impossible, therefore developing a high local economy requires the regional development paradigm from Garlick (Stimson) saying that theoretical and operational approaches in regional economic development are now distinguished based on focus one of the following three perspectives [21].

a. Regional economic success is a local accumulation that is essentially superior local productivity. Competitive regional development results from the existence of free 
markets and institutions that operate as rational actors with standardized rules.

b. Regional development is driven by a complex process of integrating something softer, including social capital, trust, loyalty and learning of the region, power relations and control in organizations and organizing culture.

c. The region has various attributes, economic, social, natural, historical, cultural and human attributes that can be used as potential for development. The crucial issue is the entrepreneurial capacity of the region's human resources to manage the existing potential.

From the above, the collaboration carried out in the Selingkar Wilis area is expected to be a link that can turn potential conflicts of interest between regions into a mutually beneficial development potential.

\subsection{Form of management of inter-regional cooperation in the Selingkar Wilis region}

As explained by Pratikno, in the previous section, the management and development of inter-regional cooperation is one of the principles that must exist in the implementation of inter-regional cooperation.
Before the collaboration goes on, the six regions that will cooperate through the facilitation of the provincial government will determine the form of cooperation to be carried out because this form of inter-regional cooperation will later have an impact on the implementation of activities agreed upon in inter-regional cooperation effectively and efficiently, determining the form of cooperation between regions correctly. Of course, it has been through a thorough study by the cooperating regions, in this Selingkar Wilis collaboration the form used is jointly-formed authorities, namely the formation of joint authority for the smooth cooperation between regions. Joint authority or commonly referred to in cooperation at Selingkar Wilis is a joint secretariat which has been formed since 2014 at the time of the initiation of cooperation at Selingkar Wilis by the East Java Province, with a system of changing the secretariat chair once every two years, even though it has been established together but still not effective and cannot provide benefits to the implementation of cooperation between regions.

The establishment of an ideal model of cooperation is indeed very difficult, especially with the high ego problem described above, however in any case, cooperation between regions must be carried out and continue, the authors provide recommendations for the establishment of a joint secretariat.

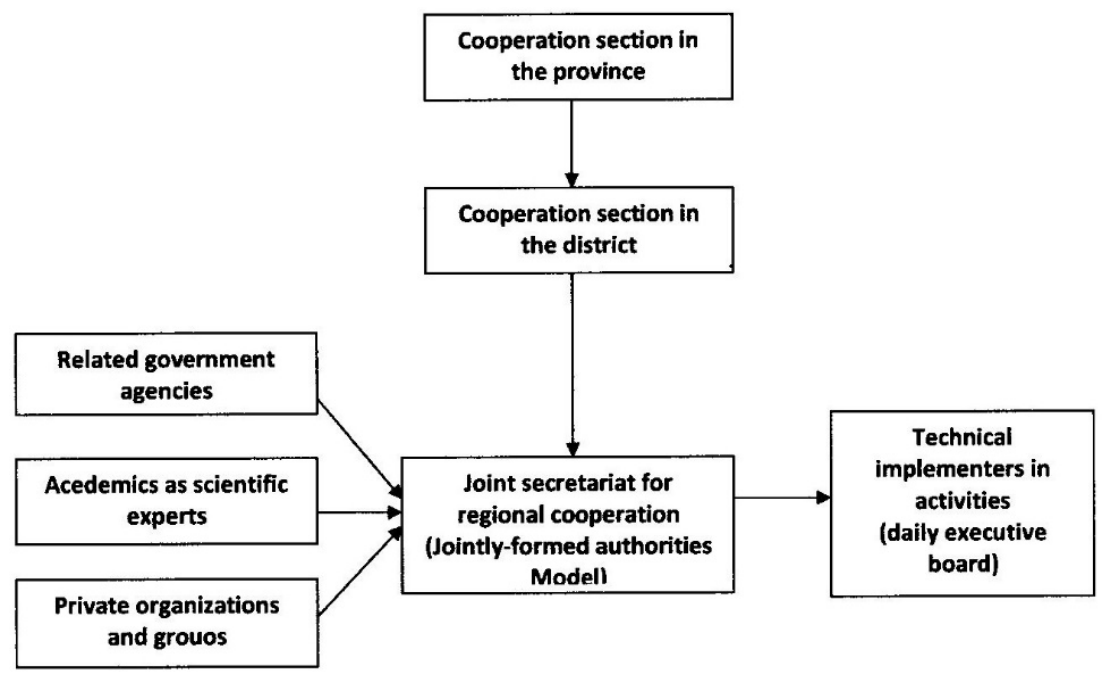

Figure 3 Alternative management of inter-regional cooperation

From the picture above, the role of the provincial government has become very central, in addition to being the main stakeholder, the provincial government must also be able to facilitate and mediate if problems occur in planning and implementing cooperation. The provincial government through the Bureau of Public Relations, Protocol and Cooperation established good relations with the cooperation at the district level, through which the provincial and district governments formed a joint secretariat.

The joint secretariat consists of professionals and practitioners, so that there is a balance between academic and practical discourse. The existence of this joint secretariat becomes very important when it must always coordinate with three components, namely the local government (through related agencies), the private sector, and the implementing technical team (daily executive board). If the inter-departmental implementation can work well, inter-regional cooperation managed by the joint secretariat will be able to be carried out and provide more benefits to the regions in each region.

\section{CONCLUSION}

From what has been explained in the previous chapter, it can be seen that the selection of appropriate inter-regional cooperation management models will make the 
[7] Ramses, A. dan Bowo Fauzi. 2007. Kerjasama Antardaerah Format Pengaturan dan Pengorganisasian. Jurnal Ilmu Pemerintahan, edisi 25 tahun 2007.

[8] Keban, Jeremias, T. 2007. Membangun Kerjasama Antar Pemerintah Daerah Dalam Era Otonomi: Isu Strategis, Bentuk, dan Prinsip. Diakses dalam: old.bappenas.go.id/get-file-server/node/8504/.

\section{ACKNOWLEDGMENT}

Thank you for this thesis supervisor, hopefully you will be given fluency to continue your research. Thank you also to all district governments in Selingkar Wilis especially for the regional cooperation and planning department.

\section{REFERENCES}

[1] Yudhoyono, S.B. 2003. Pentingnya Networking Antara Pilar Good Governance dan Antar Daerah sebagai Wujud Integritas Nasional dalam Menghadapi Era Perdagangan Bebas ASEAN tahun 2003 dalam Pratikno Kerjasama antar Daerah Kompleksitas dan Tawaran Kelembagaan. Program S2 PLOD dan J,I.P. UGM Yogyakarta

[2] Badan Penelitian dan Pengembangan Provinsi Jawa Timur. 2006. Model Kerjasama Antardaerah Dalam Pengelolaan Wisata (studi kasus di Malang Raya). Laporan penelitian internal.

[3] Irtanto dan Hari Wahyudi. 2012. Kerjasama Antardaerah dalam Pengelolaan Mata Air Umbulan Winongan Pasuruan Provinsi Jawa Timur. Jurnal Bina Praja Volume 4 Nomor 2 Juni 2012.

[4] Wahyudi, Andi, dan Maria AP. Sari. 2011. Kerjasama Antardaerah untuk Meningkatkan Pembangunan Daerah dan Pelayanan Publik di Perbatasan. Jurnal Borneo Administrator, Volume 7 Nomor 3

[5] Handayani, Fitria Andalus. 2015. Implementasi Kebijakan Kerjasama Antardaerah (Studi Tentang Penyelenggaraan Pelayanan Kesehatan Bagi Masyarakat Miskin di Kabupaten Sidoarjo dan Kabupaten Pasuruan. Jurnal Kebijakan dan Manajemen Publik, Volume 3 Nomor 2 Mei 2015.

[6] Daimul, M. Abror. 2017. Model Kerjasama Antar Pemerintah Daerah Dalam Pengelolaan Infrastruktur Publik (Studi Tentang Kerjasama Antara Pemerintah Kota Surabaya Dan Pemerintah Kabupaten Sidoarjo Dalam Pengelolaan Terminal Purabaya). Disertasi, Malang: Universitas Brawijaya.
[9] Frank, Flo and Anne Smith. 2000. The Partnership Handbook. Canada: Ministry of Public and Government Services.

[10] Lembaga Administrasi Negara. 2004. Pengelolaan Penyelenggaraan Kerjasama Antardaerah: Tinjauan Atas Beberapa Ketentuan dan Substansi Dalam Penyelenggaraan Kerjasama Antardaerah. Jakarta: LAN

[11] Mandell, Myrnal P. 2002. Type of Collaboration and Why the Differences Really Matter (Partnerships and Networks). Journal The Public Manager, Winter 2002.

[12] Yodo, Sutarman. 2013. Aspek Hukum Ekonomi Dalam Kerjasama Daerah. Yogyakarta: Genta Publishing.

[13] Warsono, Hardi. 2009. Networking dalam Intergovernmental Management. Jurnal Ilmu Administrasi dan Kebijakan Publik Dialogue, Volume 6 Nomor 1 Januari 2009

[14] Gary D, Taylor. 2003. Intergovernmental Cooperation in the 21st Century. Michigan State University, Extension Specialist, State \& Local Government.

[15] Peck, Jamie. 2004. Geography and Public Policy: Constructions of Neoliberalism. Journal Progress in Human Geography Volume 28 Nomor 3 June 2004.

[16] Pratikno. 2007. Kerjasama Antar Daerah, Kompleksitas dan Tawaran Kelembagaan. Yogyakarta: UGM Press

[17] Laporan Keterangan Pertanggungjawaban Gubernur Akhir Tahun Anggaran 2015 Provinsi Jawa Timur

[18] Mahardhani, Ardhana Januar. 2017. Peran Pemerintah Kabupaten Ponorogo Dalam Mengembangkan Kawasan Selingkar Wilis. Jurnal Ilmiah Manajemen Publik dan Kebijakan Sosial, Volume 1 Nomor 1 Tahun 2017

[19] Ma'ruf, M. Farid dan Prasetyo Isbandono. 2016. Urgensi Kerjasama Antar Daerah (Intergovernmental) Dalam Penanganan Bencana Alam di Daerah. Journal 
Fakultas Ilmu Sosial dan Politik Universitas Sebelas Maret Surakarta.

[21] Stimson, RJ.,et.al. 2006. Regional Economic Development: Analysis and Planning Strategy. Second Edition, Springer Berlin Heidelberg New York. 